\title{
Generation of reactive oxygen species in relevant cell lines as a bio-indicator of oxidative effects caused by acid mine water
}

\author{
Oluwafikemi T lji' ${ }^{1}$, June C Serem², Megan J Bester ${ }^{2}$, E Annette Venter ${ }^{1}$, Jan G Myburgh ${ }^{1}$ and Lyndy J McGaw ${ }^{1 *}$ \\ 'Department of Paraclinical Sciences, Faculty of Veterinary Science, University of Pretoria, Pretoria, South Africa \\ ${ }^{2}$ Department of Anatomy, Faculty of Health Science, University of Pretoria, Pretoria, South Africa
}

\begin{abstract}
Reactive oxygen species (ROS) production and resultant oxidative stress (OS) has been implicated as a pathway of toxicity in animal species exposed to pollutants. The gills of aquatic animals and the liver and kidneys of mammalian species are specific cellular sites of toxicity. Oxidative effects of acid mine drainage effluent (following passive and active treatment) impacting a natural stream were assessed using selected cell lines. Levels of pollutants such as heavy metals in acid mine drainage (AMD) effluent can be quantified following treatment, but it is unknown whether this is associated with equivalent reduction in toxicity. ROS production by AMD untreated (U) and after treatment (T) was quantified in a fish gill cell line (RTgill-W1) and in two mammalian cell lines (C3A human liver and Vero monkey kidney). ROS production was determined using the oxidant sensitive fluorogenic probe, $2^{\prime}, 7^{\prime}$-dichlorofluorescein diacetate (DCFH-DA) following exposure to $\mathrm{U}$ and $\mathrm{T}, \mathrm{AMD}$ water. Treatment of $\mathrm{AMD}$ water caused reduction in levels of $\mathrm{Al}, \mathrm{Zn}, \mathrm{Fe}, \mathrm{Si}$ and $\mathrm{Mn}$ while levels of $\mathrm{Cr}, \mathrm{Cu}, \mathrm{Ar}$ and $\mathrm{Hg}$ remained unchanged. A dose-dependent increase in ROS production was observed for $\mathrm{U}$ and T. ROS formation decreased from $14 \%$ to $4.5 \%, 16.4 \%$ to $7.2 \%$ and $25.3 \%$ to $17.7 \%$ in the RTgill-W1, C3A, and Vero cell lines exposed to $100 \% \mathrm{AMD}$ water, $\mathrm{U}$ and $\mathrm{T}$. The presence of $\mathrm{Mn}$ and/or other ions in treated water and subsequent ROS formation indicates that water could still be toxic to cells and requires further processing. The DCFH-DA assay in several cell lines can be used to rapidly bio-monitor quality of AMD water related to formation of ROS and subsequent cellular effects. However, cut-off levels for cellular toxicity must be established to ensure safety of this water for aquatic animals and for animal and human consumption.
\end{abstract}

Keywords: acid mine drainage, bio-monitoring, DCFH-DA, reactive oxygen species

\section{INTRODUCTION}

Coal mining is a major industry in South Africa, as coal is the principal energy source for the country (Mangena and Brent, 2006). A number of coal mines are located in the Mpumalanga Province, where over $10000 \mathrm{~km}^{2}$ of hydraulically interlinked mines host 8 of the country's 10 operational coalfired power stations (Heath et al., 2010). Most rivers have been negatively impacted by extensive industrial and mining activities in the Mpumalanga Province, threatening aquatic ecosystems (De Villiers and Mkwelo, 2009). Coal mining is the most important source of acid mine drainage (AMD) contamination affecting streams and rivers in the upper catchment of the Olifants River (Adler et al., 2007; Driescher, 2008). AMD effluent contains substances that contaminate aquatic ecosystems with effects ranging from chemical (bioavailable metal concentration), biological (acute and chronic toxicity) and ecological (loss of habitat and elimination of sensitive species) to others (Gray, 1997). Additionally, human exposure occurs by ingestion of contaminated water through drinking, preparation of food or irrigation of crops (Awofolu et al., 2005), and causes multiple organ toxicity in the brain, liver and kidneys (André et al., 1991; Bouquegneau and Joiris, 1992; Dietz et al., 1998).

\footnotetext{
${ }^{*}$ To whom all correspondence should be addressed.
}

Tel +27(0)12 529 8351; e-mail: lyndy.mcgaw@up.ac.za

Received 2 December 2015; accepted in revised form 5 January 2017
AMD is a complex mixture, and of specific concern is the presence of heavy metals that cause oxidative stress (OS), which is characterized by a disruption in the net balance between the production of reactive oxygen species (ROS) or free radicals, and antioxidant defences by redox cycling, depletion of glutathione (GSH) levels, or catalysis of the Fenton reaction (Halliwell and Gutteridge, 1989; Valko et al., 2005; Lushchak, 2008; Sevcikova et al., 2011). Metals such as $\mathrm{Fe}, \mathrm{Cu}, \mathrm{Cr}$ and $\mathrm{V}$ are redox active metals that generate ROS by redox cycling through enhancing production of oxyradicals within cells (Kelly et al., 1998). Transition metals like $\mathrm{Fe}^{2+}$ can react with $\mathrm{H}_{2} \mathrm{O}_{2}$, with the net reaction leading to formation of a hydroxyl anion and radical (Sevcikova et al., 2011). Other metals such as $\mathrm{Hg}, \mathrm{Ni}, \mathrm{Pb}$ and $\mathrm{Cd}$ impair antioxidant defence systems, for example, antioxidant enzymes and GSH (depletion via direct binding).

Assessing water quality from natural sources or water returned to the environment as wastewater is crucial to establish that no pollutants are present which could be harmful to various organisms that utilize the water. AMD effluent is usually treated for compliance before being discharged into water courses. A number of treatment technologies exist and these are used to improve the quality of AMD, such as by neutralization (hydrated lime or caustic soda is common), which is targeted at increasing water $\mathrm{pH}$ to enhance solubility of metals and consequently metal precipitation as metal hydroxides (Thompson, 1980), thus reducing metal burden and correcting acidity (Madeira et al., 2005). This outcome sometimes gives the appearance that the water is non-toxic. 
In general, water quality is assessed based on its physicochemical characteristics: the $\mathrm{pH}$, temperature, dissolved oxygen (DO), total dissolved solids, specific inorganic elements, etc. (Simpi et al., 2011). This does not furnish information on possible biological or chemical effects on the biota inhabiting the aquatic environment if polluted. When water quality monitoring is applied together with biomarkers, it provides additional detailed assessment of possible pollution effects (Bayne et al., 1988) applicable in environmental quality monitoring (Stegeman et al., 1992). Biomarkers are applied as sensitive indicators of pollution to detect underlying stressful conditions (Stegeman et al., 1992). With regard to pollution, biomarkers of exposure can be assessed based on antioxidant responses and oxidative stress parameters because pollutants enhance intracellular formation of ROS through mechanisms such as redox cycling, or cytochrome P450-dependent metabolism of polycyclic aromatic hydrocarbons and the Fenton reaction in the presence of transition metals (Regoli, 2000; Halliwell and Gutteridge, 2007; Monserrat et al., 2008).

Although ROS formation follows a normal physiological process in cellular metabolism, imbalances in generation and removal of ROS species could result in oxidative stress and biological and cellular damage (Dat et al., 2003; Mittler, 2002). ROS formation initiated by the presence of contaminants, resulting in OS, has been reported in biota exposed to pollutants. This suggests a possible connection between contaminantstimulated ROS production and resultant OS as an established pathway of toxicity in exposed organisms which is present in aquatic animals to prevent ROS-induced damage (Di Giulio et al., 1995; Kelly et al., 1998; Winston and Di Giulio, 1991). Sustained increase in ROS generation (OH-radicals, hydrogen peroxide, and superoxide anions) leads to OS, causing distress in cellular metabolism and regulation, membrane and organelle damage and/or cellular death (Kelly et al., 1998). Environmental pollutants causing OS can modify the balance between prooxidants and antioxidant forces (Winston and Di Giulio, 1991).

From the perspective of environmental monitoring and assessment of pollution effects, it is useful to determine potential pro-oxidative effects of polluted waters, which enhances oxyradical production, to give an indication of the total antioxidant capacity or resistance to toxicity triggered by ROS. Studies involving aquatic organisms like fish have reported differences in susceptibility to oxidative damage in organs such as gills, brain, muscle, liver and kidney (Oliveira et al., 2008; Monserrat et al., 2008), some of which was attributed to higher antioxidant basal levels in various tissues. Rather than measuring a limited number of antioxidants or conducting classical oxidative stress studies quantifying antioxidant efficiency individually, an alternative is to evaluate oxidative effects of polluted water on relevant cell lines to serve as a quick and easy screening method when applied together with water quality parameters.

In-vitro techniques determine possible toxicological effects of effluent compounds at the sub-cellular level versus whole or intact animal testing, offering the advantage of rapid, reproducible and more cost-effective research (Castaño et al., 2003; Bols et al., 2005). These in-vitro systems have been extremely useful in the following studies: cytotoxicity (Environment Canada, 1990), drug metabolism and toxicity (LeCluyse, 2001), molecular toxicity (Blaauboer et al., 1998), and predicting biological reactivity of potential toxic compounds (Barratt, 2000).

Cell line use in toxicity testing involving environmental contaminants has been widely reported (Maruoka, 1978;
Kfir et al., 1981; Van Doren et al., 1984; Mochida, 1986; Bols et al., 2005). An advantage to using cell lines is that they allow exposure of cells directly to whole water with little toxicant lost to extraction processes or to further sample processing (Dayeh et al., 2002). Cell types representing specific cellular targets can be used, such as RTgill-W1 cell lines derived from fish gills. Fish cell lines may be used as potential alternatives to whole fish in testing environmental samples for toxicity. The RTgill-W1 and RTL-W1 liver epithelial fish cell lines from rainbow trout have been used successfully (Dayeh et al., 2005). Mammalian cell lines such as HepG2 and Vero kidney cells representing liver and kidneys, respectively, can be used to evaluate mammalian toxicity. Mammalian cell cultures have been used successfully in identifying and understanding possible effects chemicals pose to humans and in studies performed by health laboratories and water quality regulators (Rees, 1980). Richardson et al. (1977) used a mammalian cell culture assay to evaluate water quality of oil refinery effluents.

Herein, we describe OS attributable to ROS production using an oxidant sensitive fluorogenic probe, $2^{\prime}, 7^{\prime}$-dichlorofluorescein diacetate (DCFH-DA), to detect intracellular ROS formation (Rosenkranz et al., 1992) as an early stage marker for xenobiotic-induced OS in cultured fish and mammalian cell lines. DCFH-DA is a cell-permeable, non-fluorescent dye that easily crosses biological membranes because the acetate ether is uncharged; but when cleaved by intracellular esterases it becomes charged and is retained intracellularly (Pereira et al., 2003; Poljsak et al., 2005). On hydrolysis, DCFH-DA changes to non-fluorescent DCFH, but the presence or generation of ROS oxidizes DCFH to highly fluorescent dichlorofluorescein (DCF) (LeBel et al., 1992). The increase in fluorescence can be quantified and used as an index to determine overall cellular OS.

\section{MATERIALS AND METHODS}

\section{Location and description of the study area}

The study was conducted at the receiving stream 'Kromdraai' ( $25^{\circ} 46^{\prime} 05.5^{\prime \prime} S$; $\left.29^{\circ} 07^{\prime} 15.5^{\prime \prime} \mathrm{E}\right)$ located in the Highveld region close to Witbank (Mpumalanga Province, South Africa). AMD effluent from the mine passes through a wetland into a freeflowing receiving stream which is continuously dosed with a neutralizing agent in-stream to increase the water $\mathrm{pH}$ and precipitate metals as hydroxides, improving water quality.

In-situ measurements of temperature, dissolved oxygen and $\mathrm{pH}$ were conducted at the two sample collection points along the course of the stream. Temperature, dissolved oxygen and $\mathrm{pH}$ were measured using a portable multimeter (HACH HQd, USA). The water samples collected immediately after flowing through the wetland (where it undergoes passive treatment) were termed 'untreated AMD water sample' (U), while the water samples collected downstream beyond the dosing tanks (which continuously supplied the neutralization agent) were termed 'post-treated AMD water sample' (T). Samples were collected as subsurface grab samples, and placed on ice immediately for transport back to the laboratory for analysis. Water samples were analysed by the Analytical Services, Chemistry Department, CSIR, Pretoria for nutrients (ammonia, orthophosphate, phosphate, nitrate and nitrite), metals (aluminium, arsenic, chromium, copper, iron, mercury, silicon and zinc) and inorganic constituents (calcium, magnesium, potassium, sodium, chlorine and sulphates). These were all determined according to the methods of APHA (1995). Water samples for bioassays were filtered through a $0.22 \mu \mathrm{m}$ in-line filter within $2 \mathrm{~h}$ of collection 
and stored at $4^{\circ} \mathrm{C}$ at the Department of Paraclinical Sciences, Faculty of Veterinary Science, University of Pretoria.

\section{Cell cultivation}

The C3A cell line (derivative of HepG2), purchased from the American Type Culture Collection (ATCC CRL-10741), and Vero monkey kidney cells (from the collection of the Department of Veterinary Tropical Diseases, Faculty of Veterinary Science, University of Pretoria) were grown in vented filter-cap flasks at $37^{\circ} \mathrm{C}$ in Minimal Essential Medium (MEM, Sigma-Aldrich, USA). Vero monkey kidney cell culture medium was supplemented with $0.1 \%$ gentamicin (Virbac, PHENIX, SA) and $5 \%$ foetal calf serum (FCS, Highveld Biological ${ }^{\circ}$ South Africa]), while the C3A cells were grown in antibioticfree medium supplemented with $10 \%$ FCS and $1 \mathrm{mM}$ sodium pyruvate (Sigma-Aldrich, St. MO, USA). Cells of a sub-confluent culture were harvested and centrifuged at $200 \mathrm{x} g$ for $2 \mathrm{~min}$, and re-suspended in growth medium supplemented as above, and $100 \mu \mathrm{l}\left(5 \times 10^{4} \mathrm{cells} / \mathrm{mL}\right)$ were plated in each well of columns 2 to 11 of a 96 -well microtitre plate. The plates were incubated for $24 \mathrm{~h}$ at $37^{\circ} \mathrm{C}$ in a $95 \%$ air $5 \% \mathrm{CO}_{2}$ humidified environment.

The RTgill-W1 cell line (ATCC CRL2523) was cultured in Leibovitz's L15 medium supplemented with $12 \%$ foetal calf serum (FCS, Highveld Biological South Africa) in atmospheric air at $20^{\circ} \mathrm{C}$. Cells from a sub-confluent culture were re-suspended in cell culture medium supplemented with $10 \%$ FCS and 2\% penicillin-streptomycin (5 $000 \mathrm{U} / \mathrm{L}$ penicillin, $5000 \mu \mathrm{g} / \mathrm{mL}$ streptomycin, Gibco Life Technologies, USA).

\section{DCFH-DA assay for ROS generation}

A $50 \mu \mathrm{L}$ aliquot of $75 \mu \mathrm{M}$ DCFH-DA was added to $100 \mu \mathrm{l}$ of medium per well to give a final concentration of $25 \mu \mathrm{M}$ DCFH-DA. After the cells were exposed for $45 \mathrm{~min}$ in $95 \%$ air $5 \% \mathrm{CO}_{2}$ at $37^{\circ} \mathrm{C}$ for the $\mathrm{C} 3 \mathrm{~A}$ and Vero monkey kidney cells, and at room temperature in atmospheric air for the RTgill-W1 cells, the excess extracellular DCFH-DA was removed by 2 washes of phosphate-buffered saline (PBS).

In order to assess ROS formation, the adherent cells with intracellular DCFH-DA were exposed to varying concentrations of AMD from the untreated and treated AMD samples. Dilutions of $100 \%$ (whole effluent), i.e., $75 \%, 50 \%, 25 \%, 12.5 \% 6.25 \%$, $3.125 \% 1.562 \%$ and $0.781 \%$, were prepared using ultra-pure Milli-Q water that also served as the negative control. For the positive control, 2,2'-azobis-2-methyl-propanimidamide dihydrochloride (AAPH) was used at $4 \mathrm{mg} / \mathrm{mL}$ dissolved in Milli-Q water. The experiments were performed in triplicate for each concentration and treatment, and the entire experiment was repeated twice to verify results. AAPH is a water-soluble azo compound, which is used extensively as a free radical generator; it is used often in the study of lipid peroxidation and the characterization of antioxidants (Liégeois et al., 2000). Following the breakdown of AAPH, molecular nitrogen and 2 carbon radicals are produced which may then combine to produce stable products or react with molecular oxygen to give peroxyl radicals. The fluorescence was measured using a FLUOstar fluorescence plate reader (BMG, LABTECH, Germany) with temperature maintained at $37^{\circ} \mathrm{C}$ using a $485 / 520 \mathrm{~nm}$ excitation/emission filter. The fluorescence from each well was captured, digitized, and stored on a computer using OPTIMA software. Readings were taken at intervals of $120 \mathrm{~s}$ in a selected 30 -cycle period up to $1 \mathrm{~h}$.

\section{Data analysis}

Reactive oxygen species formation was expressed as a gradient of the fluorescent units of the oxidized dye DCFH-DA from 0 to $1 \mathrm{~h}$ in the different concentration ranges expressed as a percentage of the positive control, AAPH, which was given a value of $100 \%$ toxicity. The Milli-Q water, which served as the negative control, was given a value of $0 \%$.

ROS formation was calculated using the formula:

$$
\frac{\text { Gradient of sample }- \text { gradient of Milli }-Q \text { water })}{\text { (gradient of AAPH }- \text { gradient of Milli }-Q \text { water })} \times 100
$$

The net change in fluorescence per well was calculated by taking an average of the change in fluorescence over time. The advantage of this method is that it calculates the net changes in fluorescence, such that the calculated data directly reflect the percentage changes of fluorescence over time from the cells in the same well. This method further cancels out the background fluorescence in each well and, therefore, does not require a 'no cell' control. Statistical analyses were performed with SPSS version 8.0 (SPSS Inc., Chicago IL) software, using analysis of variance (ANOVA) followed by Fisher's Protected Least Squares difference post-hoc test for individual comparisons.

\section{RESULTS}

The $\mathrm{pH}$ measured at the two sample collection stations varied considerably (Table 1). Significant acidification of the water $\mathrm{pH}$ at 3.65 was observed from the collection point emanating from the wetland $\mathrm{U}$ into the receiving stream $\mathrm{T}$.

EC values obtained for $\mathrm{U}$ and $\mathrm{T}$ ( 320 and $326 \mathrm{mS} / \mathrm{m}$ ) water samples were higher than the recommended guidelines stipulated for industrial and domestic use $(250 \mathrm{mS} / \mathrm{m}, 70 \mathrm{mS} / \mathrm{m})$. Comparable levels for some nutrients, i.e., total phosphorus, orthophosphate and ammonia were obtained for $\mathrm{U}$ and $\mathrm{T}$, whilst a small increase in the level of nitrate and nitrite for $\mathrm{T}$ vs. $\mathrm{U}$ was observed. Specific inorganic constituents like $\mathrm{Na}, \mathrm{Mg}, \mathrm{K}$, and $\mathrm{Ca}$ were present in high concentrations in $\mathrm{U}$ and $\mathrm{T}$ although set guideline levels were unavailable in some instances.

The metals $\mathrm{Al}, \mathrm{Cr}, \mathrm{Cu}, \mathrm{Fe}, \mathrm{Zn}, \mathrm{As}, \mathrm{Hg}, \mathrm{Mn}$ and Si were analysed in their dissolved states. Metal analyses performed on water samples from the discharge site showed values for Fe, $\mathrm{Zn}$ and $\mathrm{Mn}$ to be much higher than the maximum recommended values for discharged wastewater used for industrial purposes (Government Gazette, 1984; DWAF, 2004). Guideline values for wastewater or effluent produced by or resulting from the use of water for industrial purposes for rivers and dams and suitable for protection of aquatic life are also presented in Table 1 (DWAFEC, 1980). However, downstream end-users access water for drinking and food preparation and so guidelines relating to the safety of water for domestic use and human consumption are also presented in Table 1. No set guideline values were available for $\mathrm{Al}$ and $\mathrm{Si}$. The concentrations of As, $\mathrm{Hg}$ and $\mathrm{Cr}$ remained unchanged in $\mathrm{U}$ and $\mathrm{T}$.

The in-stream neutralization process effectively removed $\mathrm{Fe}$, $\mathrm{Al}, \mathrm{Zn}$ and $\mathrm{Si}$ from the water and the levels of $\mathrm{Fe}$ and $\mathrm{Zn}$ posttreatment fell within recommended guidelines for industrial effluent and domestic use. In general, $\mathrm{U}$ and $\mathrm{T}$ water samples presented higher metal levels than recommended guidelines and this was especially noticeable for $\mathrm{Mn}, \mathrm{Al}$, and $\mathrm{Zn}$. A slight increase in sulphate levels following neutralization was observed, and the levels of Mn remained high post treatment at $39 \mathrm{mg} / \mathrm{L}$. Following neutralization as a treatment option, total dissolved solids (TDS) levels of $\mathrm{Na}, \mathrm{Ca}, \mathrm{K}$, and $\mathrm{Mg}$ increased downstream when comparing $\mathrm{T}$ and $\mathrm{U}$, and an increase in alkalinity was observed. 
TABLE 1

Water chemistry analytes of AMD water samples ( $n=2$ determinations) collected at Kromdraai, Mpumalanga, South Africa compared to guideline values (DWAF, 1996, 2004, 2007) for effluent produced by or resulting from the use of water for industrial purposes, and South African water guidelines for domestic use.

\begin{tabular}{|c|c|c|c|c|c|}
\hline \multicolumn{6}{|c|}{ Metals present as ions dissolved in water } \\
\hline Analysis & Unit & $\begin{array}{l}\text { Untreated } \\
\text { AMD }\end{array}$ & $\begin{array}{l}\text { Treated } \\
\text { AMD }\end{array}$ & $\begin{array}{l}\text { Guidelines } \\
\text { for industrial use }\end{array}$ & $\begin{array}{l}\text { Guidelines for } \\
\text { domestic use }\end{array}$ \\
\hline Potassium $\left(\mathrm{K}^{+}\right)$ & $\mathrm{mg} / \mathrm{L}$ & 9 & 11 & 0.1 & $\mathrm{~N} / \mathrm{A}^{*}$ \\
\hline Sodium $\left(\mathrm{Na}^{+}\right)$ & $\mathrm{mg} / \mathrm{L}$ & 43 & 120 & N/A & 100 \\
\hline Calcium $\left(\mathrm{Ca}^{2+}\right)$ & $\mathrm{mg} / \mathrm{L}$ & 475 & 561 & N/A & $\mathrm{N} / \mathrm{A}$ \\
\hline Magnesium $\left(\mathrm{Mg}^{2+}\right)$ & $\mathrm{mg} / \mathrm{L}$ & 160 & 162 & N/A & 170 \\
\hline Alkalinity $\left(\mathrm{CaCO}_{3}\right.$ levels $)$ & $\mathrm{mg} / \mathrm{L}$ & 2.75 & 6.4 & 20 & $20-300$ \\
\hline Sulphate $\left(\mathrm{SO}_{4}^{2-}\right)$ & $\mathrm{mg} / \mathrm{L}$ & 2315 & 2336 & 1400 & 200 \\
\hline Chloride $\left(\mathrm{Cl}^{-}\right)$ & $\mathrm{mg} / \mathrm{L}$ & 3.5 & 3.5 & N/A & 250 \\
\hline Ammonia $\left(\mathrm{NH}_{4}^{+}\right)$ & $\mathrm{mg} / \mathrm{L}$ & 6.7 & 6.45 & 1 & N/A \\
\hline Nitrate \& nitrite $\left(\mathrm{NO}_{3}^{-}\right)$ & $\mathrm{mg} / \mathrm{L}$ & 2.3 & 3.6 & 1.5 & 6 \\
\hline Orthophosphate $\left(\mathrm{PO}_{4}^{3-}\right)$ & $\mathrm{mg} / \mathrm{L}$ & 0.15 & 0.15 & 1 & N/A \\
\hline Total phosphorus (TP) & $\mathrm{mg} / \mathrm{L}$ & $<0.25$ & $<0.25$ & N/A & N/A \\
\hline Electrical conductivity & $\mathrm{mS} / \mathrm{m} 25^{\circ} \mathrm{C}$ & 320 & 326 & 250 & 70 \\
\hline $\mathrm{pH}$ & $20^{\circ} \mathrm{C}$ & 3.65 & 8 & $5.5-7.5$ & $6-9$ \\
\hline Chemical oxygen demand (COD) & $\mathrm{mg} / \mathrm{L}$ & 10 & 33 & 30 & N/A \\
\hline Dissolved oxygen (DO) & $\mathrm{mg} / \mathrm{L}$ & 7.1 & 5.05 & 5.8 & N/A \\
\hline Iron $\left(\mathrm{Fe}^{2+/ 3+}\right)$ & $\mathrm{mg} / \mathrm{L}$ & 0.36 & $<0.01$ & 0.03 & 0.1 \\
\hline Manganese $\left(\mathrm{Mn}^{2+/ 3+}\right)$ & $\mathrm{mg} / \mathrm{L}$ & 65 & 39 & 0.1 & 0.05 \\
\hline $\operatorname{Zinc}\left(\mathrm{Zn}^{2+}\right)$ & $\mathrm{mg} / \mathrm{L}$ & 3.4 & 0.044 & 0.3 & 1 \\
\hline $\operatorname{Arsenic}\left(\mathrm{As}^{3+}\right)$ & $\mathrm{mg} / \mathrm{L}$ & $<0.001$ & $<0.001$ & 0.1 & 0.1 \\
\hline Mercury $\left(\mathrm{Hg}^{2+}\right)$ & $\mathrm{mg} / \mathrm{L}$ & $<0.005$ & $<0.005$ & 0.02 & 0.005 \\
\hline Silica $\left(\mathrm{Si}^{4+/ 4}\right)$ & $\mathrm{mg} / \mathrm{L}$ & 9 & 2 & N/A & N/A \\
\hline Aluminium $\left(\mathrm{Al}^{3+}\right)$ & $\mathrm{mg} / \mathrm{L}$ & 28 & 0.22 & N/A & N/A \\
\hline Chromium $\left(\mathrm{Cr}^{2+/ 3+}\right)$ & $\mathrm{mg} / \mathrm{L}$ & $<0.01$ & $<0.01$ & 0.05 & N/A \\
\hline Copper $\left(\mathrm{Cu}^{+/ 2+}\right)$ & $\mathrm{mg} / \mathrm{L}$ & $<0.03$ & 0.03 & 0.02 & N/A \\
\hline
\end{tabular}

$N / A=$ not available

In this study 3 cell lines were exposed to serial dilutions of $U$ and T water samples (Fig 1-3). An increase in ROS production was observed following exposure to increasing concentrations of AMD water ( $\mathrm{U}$ and $\mathrm{T}$ ). The maximum amount of ROS generated using whole effluent for the untreated AMD water was $14 \%, 16.3 \%$ and $26.5 \%$, for the RTgill-W1, C3A and Vero cells, respectively. A direct correlation was found between \% AMD concentration and \% ROS formation for $\mathrm{U}$, with a $R^{2}$ correlation of $0.912,0.985$ and 0.945 for the RTgill-W1, C3A and Vero cell lines, respectively. The rate of decrease in ROS production with decreasing \% AMD concentration was 0.1044, 0.144 and 0.212 fluorescence units/h for the RTgill-W1, C3A and Vero cell lines, respectively. Vero cells were most sensitive to the effects of $U$ water as shown by the highest level of ROS production (\% of positive control) observed for all cell lines following exposure to whole effluent.

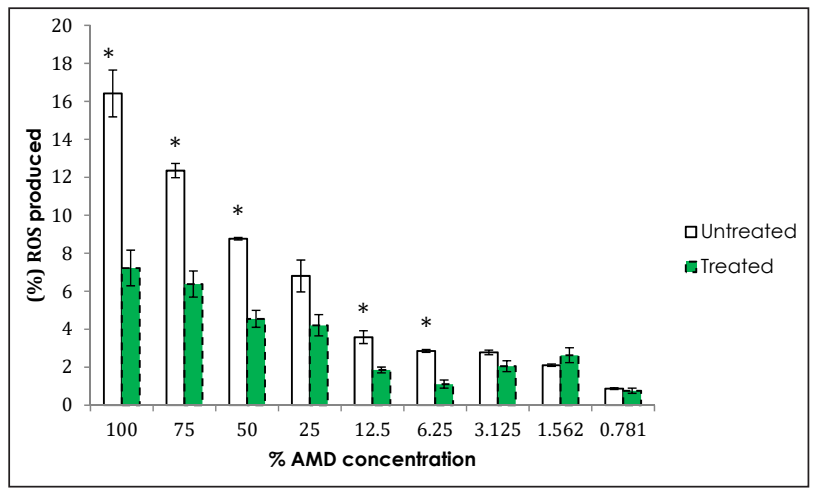

Figure 1

Percentage (\%) ROS produced in C3A cells. Data is an average of 9 data points \pm SEM. ${ }^{*}$ refers to statistical significance determined using one-way ANOVA $(p<0.05)$. 


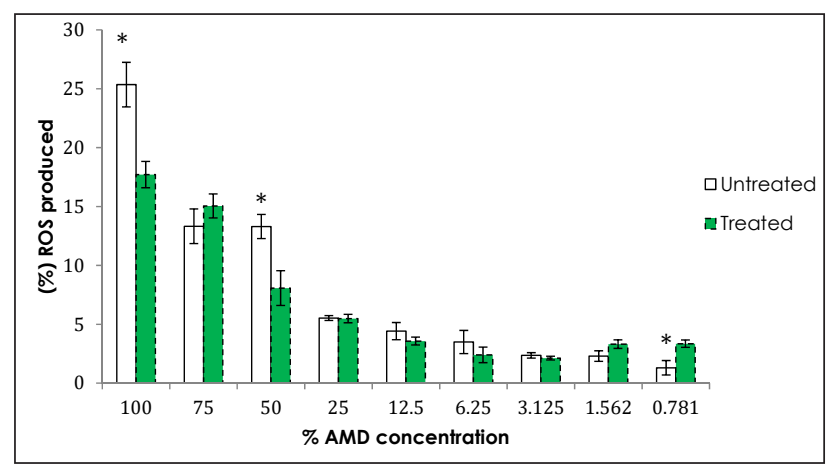

Figure 2

Percentage (\%) ROS produced in Vero cells. Data is an average of 9 data points $\pm S E M$. * refers to statistical significance determined using one-way ANOVA $(p<0.05)$.

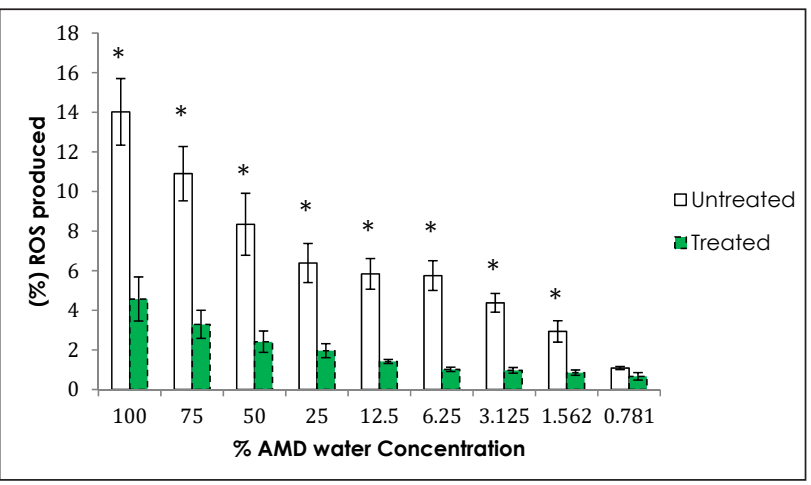

Figure 3

Percentage (\%) ROS produced in RTgill-W1cells. Data is an average of 9 data points \pm SEM. ${ }^{*}$ refers to statistical significance determined using one-way ANOVA $(p<0.05)$.

Following treatment, the maximum amount of ROS generated for the treated AMD water was $4.56 \%, 7.22 \%$ and $17.71 \%$ for the RTgill-W1, C3A and Vero cells, respectively. A direct correlation was found between \% AMD concentration and $\%$ ROS formation for T with a $R^{2}$ correlation of $0.983,0.902$ and 0.969 for the RTgill-W1, C3A and Vero cell lines, respectively. The rate of decrease in ROS production expressed in terms of fluorescence units/h with decreasing \% AMD concentration was $0.0358,0.0601$ and 0.156 for the RTgill-W1, C3A and Vero cell lines, respectively. Fold change in gradient $U$ vs. $T$ was 2.916, 2.39 and 1.36 for each respective cell line, indicating that treatment of AMD water resulted in a decrease in ROS.

Vero cells were most sensitive to treated AMD water at varying concentrations. They were consistently sensitive in terms of $\%$ ROS generation using untreated AMD water samples when compared to the C3A and the RTgill-W1 cell lines.

\section{DISCUSSION}

A number of anthropogenic activities resulting in pollution have been associated with pro-oxidant or oxyradical production in aquatic organisms within the aquatic environment (Winston and Di Giulio, 1991; Bainy et al., 1996). As an indicator of oxidative stress, evaluating loss of specific antioxidants and/or generation of oxidation products is employed. A commonly used method is the TOSC (total oxyradical scavenging capacity) that quantifies the overall tissue capacity to scavenge different forms of ROS, hence providing a general picture of the oxidative stress of that particular tissue (Regoli and Winston, 1999; Regoli et al., 2002). Regoli et al. (2004) reported the successful use of the TOSC method at detecting depleted antioxidant defences in mussels (Mytilus galloprovincialis) transplanted to polluted areas, by correlating the influence of pollution to oxidative DNA damage. The advantage of TOSC (and, by extension, an equivalent methodology) is that it establishes an integrated antioxidant response of an organism or tissue against a particular type of ROS, like peroxyl, or radicals.

Effluent discharge from mining activity impacts water bodies negatively, usually causing a resultant increase in dissolved metals, such as $\mathrm{Al}, \mathrm{Fe}, \mathrm{Zn}, \mathrm{Mn}, \mathrm{Cu}$, or Cd (Grippo and Dunson, 1996). Aquatic pollutants have potential to induce formation of ROS in organisms resulting in OS (Lesser, 2006) that can lead to cellular dysfunction and possibly death. The presence of transition redox-active transition metals can initiate a reaction to produce a highly reactive oxygen species (ROS), the hydroxyl radical $\left(\mathrm{OH}^{-}\right)$, via the Fenton reaction (Kelly et al., 1998).

The use of in-vitro contaminant-stimulated ROS production has been demonstrated in a number of species for a number of contaminants (Livingstone, 2001). In this study the RTgill-W1, and 2 mammalian cell lines (C3A and Vero) that represent specific cellular sites of oxidative damage in mammalian species, including humans, were included. An increased ROS generation was observed following exposure to $\mathrm{U}$ and $\mathrm{T}$. Net increases in ROS indicates a state of oxidative stress (Livingstone, 2001). Synergistic effects between different metals can cause increased levels of oxidative damage. $\mathrm{Al}, \mathrm{Fe}, \mathrm{Zn}$ and $\mathrm{Mn}$ levels were present at concentrations that were above permissible guidelines and as such may have played a role in the observed increased ROS formation in U (Table 1). DiToro et al. (2001) reported that the presence of free metal ion concentration is suggestive of availability and likely toxicity. Of the metals present in the effluent, $\mathrm{Fe}, \mathrm{Cu}, \mathrm{Cr}$ and $\mathrm{Ar}$ are reported to generate ROS by redox recycling, while $\mathrm{Hg}$ depletes GSH and thiol-containing antioxidant enzymes. Both processes result in an increase in ROS production (see review by Ercal et al., 2001).

Metals such as $\mathrm{Al}, \mathrm{Cd}, \mathrm{U}, \mathrm{Zn}, \mathrm{Co}, \mathrm{Ni}, \mathrm{Pb}, \mathrm{Mn}$ and $\mathrm{Cu}$ have been recognized to be of potential ecotoxicological concern arising as a consequence of mining (Markich and Camiller, 1997). Metals present as free metal ions or those that form weak complexes readily become bioavailable compared to those bound to particulate matter or with strong bonds (Batley, 2004).

A direct correlation, with $R^{2}$ close to a value of 1 , was seen with \% AMD concentration and ROS generation. This implies that the presence of certain pollutants was responsible for the observed increase in ROS production. A number of environmental stressors exert toxic effects via different pathways based on their metabolism and reactivity; metals are reported to exert direct pro-oxidant effects through biochemical oxido/ reduction mechanisms by triggering apoptosis and oxidative stress (Assefa et al., 2005; Valko et al., 2005). Contreras et al. (2005) reported a significant increase in ROS and lipo-peroxide levels in seaweeds around the discharges of copper mines, while Bopp et al. (2008) reported a 25- to 35-fold ROS induction in rainbow trout gill cells exposed to $\mathrm{Cu}$ (total $\mathrm{Cu} 100 \mu \mathrm{M}, \mathrm{pH}$ 7). Exposure to a mixture of heavy metals $(\mathrm{Cu}, \mathrm{Cd}, \mathrm{Fe}$ and $\mathrm{Ni}$ ) caused a decrease in the levels of antioxidant enzymes, reduced GSH and an increase in lipid peroxidation in the gills of the freshwater fish Channa punctata (Pandey et al., 2008). Heavy metal cations have a great propensity for the $-\mathrm{SH}$ group of GSH (Viarengo, 1993). García-Alfonso (1995) also reported changes in the antioxidant activities in cultured Vero cells after $24 \mathrm{~h}$ 
exposure to $\mathrm{Fe}^{2+}$ and $\mathrm{Fe}^{3+}$. ROS formation was thought to have followed the process of interconverting through the Haber-Weiss reaction.

The decrease in ROS generation in T could be explained by the decrease in the metal load of the water sample. When low-pH AMD water containing elevated concentrations of dissolved metals was treated in-stream by dosing with the neutralizing agent, the $\mathrm{pH}$ increased abruptly, and metals such as Fe, Al, Zn and Si precipitated rapidly into colloidal and particulate forms. The rise in $\mathrm{pH}$ of the stream achieved through the in-stream alkali neutralization process resulted in complexation phenomena and consequent metal hydroxide precipitation (Madeira et al., 2005). This may have accounted for the reduced toxicity in effluent water $\mathrm{T}$, as $\%$ ROS generated using whole effluent showed a decrease from $26.5 \%$ to $17.7 \%$ in Vero monkey kidney cells, in C3A cells from $16.3 \%$ to $7.2 \%$ in C3A and $14 \%$ to $4.5 \%$ in RTgill-W1 cell lines. The persistence of $\mathrm{Mn}$ in T may be because the optimal precipitation of Mn occurs at a higher $\mathrm{pH}$ of between 9 and 10 (Means, 2004).

Another observation was the increase in inorganic ions post-treatment in $\mathrm{T}$ - this involved major cations like $\mathrm{Ca}$ and $\mathrm{Mg}$ which are reported to reduce metal bioavailability as they compete with metals for binding sites on the cell surface (Twining, 2000). A decrease in toxicity of effluent from an abandoned uranium mine was described to be concurrent with an increase in $\mathrm{pH}$ of effluent (Franklin et al., 2000).

Water chemistry parameters for metals such as $\mathrm{Al}, \mathrm{Fe}, \mathrm{Zn}$ and $\mathrm{Si}$ were reduced by 21-, 19-, 146- and 4.5-fold, respectively, in effluent water $\mathrm{T}$ (Table 1). Consistent with these findings were those of Moore (1992), where differences in ROS formation were observed in isolated hepatocytes of dab (Limanda limanda) from polluted sites versus cleaner sites in the German Bight, North Sea (Schlezinger et al., 2000). Choi and Oris (2000) likewise reported increased ROS production involving a number of water-borne contaminants like duroquinone (component of pulp mill effluent) and benzo[a]pyrene (BaP) diones.

A number of water parameters fell short of the recommended standards. High concentrations of $\mathrm{SO}_{4}$, together with higher EC and TDS values, were observed. Increase in conductivity, which is an index for TDS pollutant, indicates the level of pollution (USEPA, 1982). Inorganic ions such as $\mathrm{K}^{2+}, \mathrm{K}^{+}$, $\mathrm{Ca}^{2+}, \mathrm{Na}^{+}$and $\mathrm{Mg}^{2+}$ were present in relatively high concentrations in the AMD effluent and concentrations increased downstream post-neutralization. Richness in inorganic ions influences metal bioavailability and toxicity (Antunes, 2007) and water chemistry parameters strongly influence toxicity of metals to aquatic organisms (Paquin et al., 2002). In categorizing the level of AMD impact using water quality parameters that suggest AMD impact, the site could be termed as being highly impacted (Federal Water Pollution Control Administration, 1968) raising a question of compliance to effluent discharge limits, toxicity to water life and suitability for downstream end-users.

Differences in ROS formation were observed in the three cell lines (Table 2). The Vero cell line was the most sensitive (least antioxidant capacity), as it generated the most ROS across all concentrations in $\mathrm{T}$ and in higher concentrations exposed to $\mathrm{U}$. There are reports suggesting differences in vulnerability to oxidative damage (Monserrat et al., 2008; Oliveira et al., 2008). The reason for Vero cell sensitivity is unknown, but the kidneys from which they are derived are important target organs usually related to heavy metal toxicity (Gardner et al., 2006; Barbieri et al., 2009). These cell lines may also have lower antioxidant basal levels, making them more prone to ROS formation, and unsuitable for this purpose.
TABLE 2

Cell line with highest sensitivity to untreated and treated AMD at varying concentration

\begin{tabular}{|c|l|l|}
\hline \% AMD water & Untreated & Treated \\
\hline 100 & Vero & Vero \\
\hline 75 & C3A /Vero/RTgill-W1 & Vero \\
\hline 50 & Vero & Vero \\
\hline 25 & Vero/C3A & Vero/C3A \\
\hline 12.5 & C3A /Vero/RTgill-W1 & Vero \\
\hline 6.25 & RTgill-W1 & Vero \\
\hline 3.125 & RTgill-W1 & Vero/C3A \\
\hline 1.562 & C3A /Vero/RTgill-W1 & Vero/C3A \\
\hline 0.781 & C3A /Vero/RTgill-W1 & Vero \\
\hline & & \\
\hline
\end{tabular}

The C3A and the RTgill-W1 cells derived from human liver and fish gills, respectively, displayed lower ROS formation and, by extension, higher antioxidant capacity on exposure to $U$ and T AMD water. This may be connected with the fact that the cells were derived from organs actively involved with metabolism of xenobiotics. Both cell lines exhibited a decrease in the rate of fluorescence (ROS formation) with decreasing \% AMD concentration. We observed a more consistent dose-response relationship using the $\mathrm{C} 3 \mathrm{~A}$ and the RTgill-W1 cells. A higher fold change in gradient $\mathrm{U}$ vs $\mathrm{T}$ observed in these cell lines suggests their adaptability and possibly suitability to changes in water conditions. The changes with regard to this experiment stemmed from treatment of $\mathrm{U}$ to $\mathrm{T}$, which resulted in lower metal concentration and concurrent decrease in ROS.

In the whole animal, the intact gill is described as one of the most critical sites of toxicity to waterborne contaminants in fish (Wood, 2001), because it is immersed in water and its function involves the uptake of minerals including metals (Bury et al., 2003). Gills have previously been reported to become fatally damaged following exposure to metals (Castaño, 2003). Generally, the use of fish cell lines in aquatic research involving aquatic contaminants is believed to be better suited than mammalian cell lines, because cells from fish cell lines most probably better reflect the properties of the fish from which they were initiated than cells of mammalian origin (Bols et al., 2005).

In parallel to ROS measurements, cytotoxicity of effluents was determined within a $1 \mathrm{~h}$ period using whole effluent (results not shown). Since a clear positive correlation has been reported between the number of viable cells and consequent increase in DCF fluorescence (Bopp et al., 2007), this was necessary so that exposed cells do not become damaged from cytotoxic effects, leading to an underestimate of potential ROS formation.

\section{CONCLUSION}

This study showed that the water quality parameters of the receiving stream were adversely impacted by AMD discharge and the presence of metals at environmentally-relevant concentrations may have contributed to observed increased ROS formation in cell lines exposed to $\mathrm{U}$ and $\mathrm{T}$. Since biological diversity and physiological state of the biota are direct indices 
of water quality, in-vitro techniques involving cellular ROS formation may serve as an alternative relevant model for evaluating potential oxidative effects of polluted waters. This model system using cell lines that represent the target tissues of toxicity can be routinely implemented as a fast, easy and straightforward manner to estimate the possible consequence of exposure to certain aquatic environmental pollutants involving AMD, because antioxidant competence is a mutually-inclusive measurement in biomonitoring research (Monserrat et al., 2008). A limitation is that there is no standard cut-off level for ROS formation that indicates the degree of safety. Another drawback might be that specific biomarkers to link to the antioxidant response were not used in this study.

Bearing in mind that antioxidant competence is measured by ROS determination, this method, applied together with other bioassays related to environment health research, could be a useful alternative to whole animal testing and exposure to polluted streams for detection of onset of OS.

\section{ACKNOWLEDGEMENTS}

OTI is grateful to the Schlumberger Stichting Fund,

The Netherlands for a fellowship. The National Research Foundation and the Department of Paraclinical Sciences (University of Pretoria) are acknowledged for research funding [Project number: V027-12].

\section{REFERENCES}

ADLER R, CLAASSEN M, GODFREY L and TURTON AR (2007) Water, mining and waste: A historical and economic perspective on conflict management in South Africa. Econ. Peace Secur. J. 2 32-41. https://doi.org/10.15355/epsj.2.2.33

APHA, AWWA and WEF (American Public Health Association, American Water Works Association and Water Environment Federation) (1995) Standard Methods for the Examination of Water and Wastewater (19 ${ }^{\text {th }}$ edn.) American Public Health Association, Washington, DC.

ANDRE JM, BOUDOU A, RIBEYRE F and BERNHARD M (1991) Comparative study of mercury accumulation in dolphins (Stenella coeruleoalba) from French Atlantic and Mediterranean coasts. Sci. Total Environ. 104 191-209. https://doi. org/10.1016/0048-9697(91)90072-M

ANTUNES SC, PEREIRA R and GONÅALVES F (2007) Acute and chronic toxicity of effluent water from an abandoned uranium mine. Arch. Environ. Contam. Toxicol. 53 207-213. https://doi.org/10.1007/ s00244-006-0011-9

ASSEFA Z, VAN LAETHEM A, GARMYN M and AGOSTINIS P (2005) Ultraviolet radiation- induced apoptosis in keratinocytes: on the role of cytosolic factors. Biochim. Biophys. Acta 1755 90-106. https://doi. org/10.1016/j.bbcan.2005.04.001

AWOFOLU OR, MBOLEKWA Z, MTSHEMLA V and FATOKI OS (2005) Levels of trace metals in water and sediments from Tyume river and its effects on an irrigated farmland. Water SA 31 87-94. https://doi.org/10.4314/wsa.v31i1.5124

BAINY ACD, SAITO E, CARVALHO PSM and JUNQUEIRA VBC (1996) Oxidative stress in gill, erythrocytes, liver and kidney of Nile Tilapia (Oreochromis niloticus) from a polluted site. Aquat. Toxicol. 34 151-162. https://doi.org/10.1016/0166-445X(95)00036-4

BARBIERI E (2009) Concentration of heavy metals in tissues of green turtles (Chelonia mydas) sampled in the Cananeia estuary, Brazil. J Oceanogr. 57 243. https://doi.org/10.1590/s1679-87592009000300007

BARRATT MD (2000) Prediction of toxicity from chemical structure. Cell Biol. Toxicol. 16 1-13. https://doi.org/10.1023/A:1007676602908

BATLEY GE, APTE SC and STAUBER JL (2004) Speciation and bioavailability of trace metals in water. Progress since 1982. Aus. J. Chem. 57 903-919. https://doi.org/10.1071/CH04095
BAYNE BL, CLARKE KR and GRAY JS (1988) Background and rationale to a practical workshop on biological effects of pollutants. Mar. Ecol. Prog. Ser. 46 1-5. https://doi.org/10.3354/meps046001

BLAAUBOER BJ, BALLS M, BARRATT M, CASATI S, COECKE S, MOHAMED MK, MOORE J, RALL D, SMITH KR, TENNANT R, SCHWETZ BA, STOKES WS and YOUNES M (1998) $13^{\text {th }}$ Meeting of the Scientific Group on Methodologies for the Safety Evaluation of Chemicals (SGOMSEC): Alternative testing methodologies and conceptual issues. Environ. Health Perspect. 106 413-415. https://doi. org/10.1289/ehp.98106413

BOLS NC, DAYEH VR, LEE LEJ and SCHIRMER K (2005) Use of fish cell lines in the toxicology and ecotoxicology of fish. Piscine cell lines in environmental toxicology. In: Moon TW and Mommsen TP (ed) Biochemistry and Molecular Biology of Fishes. Elsevier Science, Amsterdam.

BOPP SK, ABICHT HK and KNAUER K (2008) Copper-induced oxidative stress in rainbow trout gill cells. Aquat. Toxicol. 86 197-204. https://doi.org/10.1016/j.aquatox.2007.10.014

BOUQUEGNEAU JM and JOIRIS C (1992) Ecotoxicology of stable pollutants in cetaceans: organochlorines and heavy metals. In: Proceedings Whales: Biology - Threats - Conservation. Symposium. Royal Academy of Overseas Sciences, 5-7 June 1991, Brussels.

BURY N and GROSELL M (2003) Iron acquisition by teleost fish. Comp. Biochem. Physiol. C Toxicol. Pharmacol. 135 97-105.

CASTAÑO A, BOLS NC, BRAUNBECK T, DIERICKX P, HALDER M, ISOMAA B, KAWAHARA K, LEE LEJ, MOTHERSILL C, PART P and co-authors (2003) The use of fish cells in ecotoxicology. ATLA 31 317-351.

CHOI J and ORIS JT (2000) Evidence for oxidative stress in bluegill sunfish (Lepomis macrochirus) liver microsomes simultaneously exposed to solar ultraviolet radiation and anthracene. Environ. Toxicol. Chem. 19 1795-1799. https://doi.org/10.1002/etc.5620190713

CONTRERAS L, MOENNE A and CORREA JA (2005) Antioxidant responses in Scytosiphon lomentaria (Phaeophyceae) inhabiting copper-enriched coastal environment. J. Phycol. 41 1184-1195. https://doi.org/10.1111/j.1529-8817.2005.00151.x

DAT JF, PELLINEN R, BEECKMAN T, VAN DE COTTE B, LANGERBARTELS C, KANGASJÄRVI J, INZÉ D and VAN BREUSEGEM F (2003) Changes in hydrogen peroxide homeostasis trigger an active cell death process in tobacco. Plant J. 33 621-632. https://doi.org/10.1046/j.1365-313X.2003.01655.x

DAYEH VR, LYNN DH and BOLS NC (2005) Cytotoxicity of metals common in mining effluent to rainbow trout cell lines and to the ciliated protozoan, Tetrahymena thermophila. Toxicol. In Vitro 19 399-410. https://doi.org/10.1016/j.tiv.2004.12.001

DAYEH VR, SCHIRMER K and BOLS NC (2002) Applying whole water samples directly to fish cell cultures in order to evaluate the toxicity of industrial effluent. Water Res. 36 3727-3738. https://doi. org/10.1016/S0043-1354(02)00078-7

DE VILLIERS S and MKWELO ST (2009) Has monitoring failed the Olifants River, Mpumalanga? Water SA 35 671-676. https://doi. org/10.4314/wsa.v35i5.49193

DWAF (Department of Water Affairs and Forestry, South Africa) (2004) National Water Resource Strategy. September. Department of Water Affairs and Forestry, Pretoria. 37 pp.

DWAF (Department of Water Affairs and Forestry, South Africa) (2004) Olifants Water Management Area: Internal Strategic Perspective. Report P WMA 04/0000/00/0304. Department of Water Affairs and Forestry, Pretoria.

DWAF (Department of Water Affairs and Forestry, South Africa) (2007) Best Practice Guideline H4: Water Treatment. Department of Water Affairs and Forestry, Pretoria.

DWAFEC (Department of Water Affairs, Forestry and Environmental Conservation, South Africa) (1980) Hydrological Research Institute, Technical Report No. TR 108, August 1980. Summarized Water Quality Criteria. Department of Water Affairs, Forestry and Environmental Conservation, Pretoria.

DWAF (Department of Water Affairs and Forestry, South Africa) (1996) South African Water Quality Guidelines, Aquatic Ecosystems ( $1^{\text {st }}$ edn). Vol. 7. Department of Water Affairs and Forestry, Pretoria. 
DIETZ R, NØRGAARD J and HANSEN JC (1998) Have arctic mammals adapted to high cadmium levels? Mar. Pollut. Bull. 36 490-492. https://doi.org/10.1016/S0025-326X(98)00045-9

DIGIULIO RT, BENSON WH, SANDERS BM and VANVELD PA (1995) Biochemical mechanisms: Metabolism, adaptation and toxicity. In: Rand GW (ed.) Fundamentals of Aquatic Toxicology. Taylor and Francis, Washington.

DITORO DM, KAVVADAS CD, MATHEW R, PAQUIN PR and WINFIELD RP (2001). The persistence and availability of metals in aquatic environments. International Council on Metals and the Environment, Ottawa, Canada. 73 pp.

DRIESCHER AC (2008) A water quality study of Loskop Dam and the upper catchment of the Olifants River. MSc thesis, University of the Free State, Bloemfontein, South Africa.

ENVIRONMENT CANADA (1990) Biological test method: acute lethality test using rainbow trout. EPS 1/RM/9, Environmental Protection Series. Environment Canada, Ottawa.

ERCAL N, GURER-ORHAN H and AYKIN-BURNS N (2001) Toxic metals and oxidative stress Part I: Mechanisms involved in metal induced oxidative damage. Curr. Top. Med. Chem. 1 529-539. https:// doi.org/10.2174/1568026013394831

FEDERAL WATER POLLUTION CONTROL ADMINISTRATION (1968) Stream pollution by coalmine drainage, Upper Ohio River Basin. US Department of the Interior, Ohio Basin Region.

FRANKLIN NM, STAUBER JL, MARKICH SJ and LIM RP (2000) $\mathrm{pH}$-dependent toxicity of copper and uranium to a tropical freshwater alga (Chlorella sp.). Aquat. Toxicol. 48 275-289.

GARCÍA-ALFONSO C, LÓPEZ-BAREA J, SANZ P, REPETTO G and REPETTO M (1996) Changes in antioxidative activities induced by $\mathrm{Fe}$ (II) and Fe (III) in cultured Vero cells. Arch. Environ. Contam. Toxicol. 30 431-436. https://doi.org/10.1007/BF00213392

GARDNER SC, FITZGERALD SL, VERGAS BA and RODRIGUEZ LM (2006) Heavy metal accumulation in four species of sea turtles from the Baja California peninsula, Mexico. BioMetals 19 91. https://doi. org/10.1007/s10534-005-8660-0

GRAY NF (1997) A substrate classification index for the visual assessment of the impact of acid mine drainage in lotic systems. Water Res. 30 1551-1554. https://doi. org/10.1016/0043-1354(95)00313-4

GRIPPO RS and DUNSON WA (1996) The body ion loss biomarker, Interactions between trace metals and low $\mathrm{pH}$ in reconstituted coalmine polluted water. Environ. Toxicol. Chem. 15 1955-1963. https://doi.org/10.1002/etc.5620151114

HALLIWELL B and GUTTERIDGE JMC (1989) Free Radicals in Biology and Medicine. Oxford University Press, New York. 617-783.

HALLIWELL B and GUTTERIDGE JMC (2007) Free Radicals in Biology and Medicine. Oxford University Press, New York. 963 pp.

HEATH R, COLEMAN T and ENGELBRECHT J (2010) Water quality overview and literature review of the ecology of the Olifants River. WRC Report No. TT 452/10. Water Research Commission, Pretoria. $51 \mathrm{pp}$.

KELLY SA, HAVRILLA CM, BRADY TC, ABRAMO KH and LEVIN ED (1998) Oxidative stress: established mammalian and emerging piscine model systems. Environ. Health Perspect. 106 375-384. https://doi.org/10.1289/ehp.98106375

KFIR R and PROZESKY OW (1981) Detection of toxic substances in water by means of a mammalian cell culture technique. Water Res. 15 553-559. https://doi.org/10.1016/0043-1354(81)90018-X

LEBEL CP, ISCHIROPOULOS H and BONDY SC (1992) Evaluation of the probe 2',7'-dichlorofluorescin as an indicator of reactive oxygen species formation and oxidative stress. Chem. Res. Toxicol. 5 227-231. https://doi.org/10.1021/tx00026a012

LECLUYSE EL (2001) Human hepatocyte culture systems for the in vitro evaluation of cytochrome $\mathrm{P} 450$ expression and regulation. Eur. J. Pharm. Sci. 13 343-368. https://doi.org/10.1016/ S0928-0987(01)00135-X

LESSER MP (2006) Oxidative stress in marine environments: biochemistry and physiological ecology. Ann. Rev. Physiol. 68 253-278. https://doi.org/10.1146/annurev.physiol.68.040104.110001

LIEGEOIS C, LERMUSIEAU G and COLLIN S (2000) Measuring antioxidant efficiency of wort, malt and hops against the 2.2'-azobis (2-amidino- propane) dihydrochloride-induced oxidation of an aqueous dispersion of linoleic acid. J. Agric. Food Chem. 48 11291134. https://doi.org/10.1021/jf9911242

LIVINGSTONE DR (2001) Contaminant-stimulated reactive oxygen species production and oxidative damage in aquatic organisms. Mar. Pollut. Bull. 42 656-666. https://doi.org/10.1016/ S0025-326X(01)00060-1

LUSHCHAK OV, KUBRAK OI, NYKORAK MZ, STOREY KB and LUSHCHAK VI (2008) The effect of potassium dichromate on free radical processes in goldfish: possible protective role of glutathione. Aquat. Toxicol. 87 108-114. https://doi.org/10.1016/j. aquatox.2008.01.007

MADEIRA VS, ECHERT AB, SCHNEIDER CH and SCHNEIDER IAH (2005) Sulfate reduction in acid mine drainage through anaerobic treatment with sulphate reducing bacteria. In: Proceedings of the XXI Ores National Treatment Dating Extractive agents Metallurgy and Interference Processes, Degradation and Environmental Damage, November, Natal RN.

MANGENA SJ and BRENT AC (2006) Application of a Life Cycle Impact Assessment framework to evaluate and compare environmental performances with economic values of supplied coal products. J. Clean. Prod. 14 1071-1084. https://doi.org/10.1016/j. jclepro.2004.04.012

MARKICH SJ and CAMILLERI C (1997) Investigation of metal toxicity to tropical biota: Recommendations for revision of the Australian Water Quality Guidelines. Supervising Scientist Report 127, Supervising Scientist, Canberra.

MARUOKA S (1978) Estimation of toxicity using cultured mammalian cells of organic pollutants recovered from Lake Biwa. Water Res. 12 371-375. https://doi.org/10.1016/0043-1354(78)90102-1

MEANS B and TIFF H (2004) Comparison of three methods to measure acidity of coal mine drainage. In: National Meeting of the American Society of Mining and Reclamation, Lexington, KY. EPAHQ-OW-2006-0771-0142. https://doi.org/10.21000/jasmr0401249

MITTLER R (2002) Oxidative stress, antioxidants and stress tolerance. Trends Plant Sci. 7 405-410. https://doi.org/10.1016/ S1360-1385(02)02312-9

MOCHIDA K (1986) Aquatic toxicity evaluated using human and monkey cell culture assays. Bull. Environ. Contam. Toxicol. 36 523-526. https://doi.org/10.1007/BF01623546

MONSERRAT JM, VENTURA-LIMA J, RIBAS-FERREIRA, JL, ACOSTA D, GARCIA ML, RAMOS PB, MORAES TB, SANTOS LC and AMADO LL (2008) Modulation of antioxidant and detoxification response mediated by lipoic acid in the fish Corydoras paleatus (Callychthyidae). Comp. Biochem. Physiol. C 148 287-296. https://doi.org/10.1016/j.cbpc.2008.06.011

MOORE MN (1992) Molecular cell pathology of pollutant-induced liver injury in flatfish: use of fluorescent probes. Mar. Ecol. Prog. Ser. 91 127-133. https://doi.org/10.3354/meps091127

OLIVEIRA M, PACHECO M and SANTOS MA (2008) Organ specific antioxidant responses in golden grey mullet (Liza aurata) following a short-term exposure to phenanthrene. Sci. Total Environ. 39 70-78. https://doi.org/10.1016/j.scitotenv.2008.02.012

PANDEY S, PARVEZ S, ANSARI RA, ALI M, KAUR M, HAYAT F, AHMAD F and RAISUDDIN S (2008) Effects of exposure to multiple trace metals on biochemical, histological and ultrastructural features of gills of a freshwater fish, Channa punctata Bloch. Chem.-Biol. Interact. 174 183-192. https://doi.org/10.1016/j.cbi.2008.05.014

PAQUIN PR, GORSUCH JW, APTE S, BATELY G, BOWLES KC, CAMPBELL PGC, DELOS CG, DI TORO DM, DWYER RL, GALVEZ F and co-authors (2002) The biotic ligand model: A historical overview. Comp. Biochem. Physiol. C 133 3-35. https://doi. org/10.1016/s1532-0456(02)00112-6

PEREIRA EDE J, PANEK AD and ELEUTHERIO EC (2003) Protection against oxidation during dehydration of yeast. Cell Stress Chaperones 8 120-124. https://doi.org/10.1379/1466-1268(2003)008<0120:PAO $\mathrm{DDO}>2.0 . \mathrm{CO} ; 2$

POLJSAK B, GAZDAG Z, JENKO-BRINOVEC S, FUJS S, PESTI M, BÉLAGYI J, PLESNICAR S and RASPOR P (2005) Pro-oxidative vs antioxidative properties of ascorbic acid in chromium (VI)-induced damage: an in vivo and in vitro approach. J. Appl. Toxicol. 25 535-548. https://doi.org/10.1002/jat.1093 
REGOLI F (2000) Total oxyradical scavenging capacity (TOSC) in polluted and translocated mussels: a predictive biomarker of oxidative stress. Aquat. Toxicol. 50 351-61. https://doi.org/10.1016/ s0166-445x(00)00091-6

REGOLI F and WINSTON GW (1999) Quantification of total oxidant scavenging capacity of antioxidants for peroxynitrite, peroxyl radicals, and hydroxyl radicals. Toxicol. Appl. Pharmacol. 156 96-105. https://doi.org/10.1006/taap.1999.8637

REGOLI F, FRENZILLI G, BOCCHETTI R, ANNARUMMA F, SCARCELLI V, FATTORINI D and NIGRO M (2004) Timecourse variations of oxyradical metabolism, DNA integrity and lysosomal stability in mussels, Mytilus galloprovincialis, during a field translocation experiment. Aquat. Toxicol. 68 167-178. https://doi. org/10.1016/j.aquatox.2004.03.011

REGOLI F, GORBI S, FRENZILLI G, NIGRO M, CORSI I, FOCARDI S and WINSTON GW (2002) Oxidative stress in ecotoxicology: from the analysis of individual antioxidants to a more integrated approach. Mar. Environ. Res. 54 419-423. https://doi.org/10.1016/ s0141-1136(02)00146-0

REES KR (1980) Cells in culture in toxicity testing: a review. J. R. Soc. Med. 73 261-264.

RICHARDSON D, DORRIS TC, BURKS S, BROWNE RH, HIGGINS ML and LEACH FR (1977) Evaluation of a cell culture assay for determination of water quality of oil-refinery effluents. Bull. Environ. Contam. Toxicol. 18 683-690. https://doi.org/10.1007/BF01691979

ROSENKRANZ AR, SCHMALDIENT S, STUHLMEIER KM, CHEN W, KNAPP W and ZLABINGER GJ (1992) J. Immunol. Meth. 156 39-45. https://doi.org/10.1016/0022-1759(92)90008-H

SCHLEZINGER JJ, KELLER J, VERBRUGGE LA and STEGEMANN JJ (2000) 3, 3', 4, 4'-tetrachlorobiphenyl oxidation in fish, bird and reptile species: relationship to cytcohrome P450 1A inactivation and reactive oxygen production. Comp. Biochem. Physiol. 125C 273-286. https://doi.org/10.1016/s0742-8413(99)00112-7

SEVCIKOVA M, MODRA H, SLANINOVA A and SVOBODOVA $\mathrm{Z}$ (2001) Metals as a cause of oxidative stress in fish: a review. Veterinarni Med. 56 (11) 537-546.

SIMPI B, HIREMATH SM, MURTHY KNS, CHANDRASHEKARAPPA KN, PATEL AN and PUTTIAH ET (2011) Analysis of water quality using physico-chemical parameters hosahalli tank in Shimoga. Glob. J. Sci. Front. Res 11 31-34.

STEGEMAN JJ, BROUWER M, DI GIULIO RT, FÖRLIN L, FOWLER BA, SANDERS BM and VAN VELD PA (1992) Molecular responses to environmental contamination: enzyme and protein systems as indicators of chemical exposure and effect. In: Huggett RJ, Kimerle RA, Mehrle PM and Bergman HL (eds) Biomarkers: Biochemical, Physiological and Histological Markers of Anthropogenic Stress. Lewis, Chelsea, MI. 235-335.

THOMPSON JG (1980) Acid mine water in South Africa and their amelioration. Water SA 6 130-134.

TWINING J, NGUYEN V, BROWN P and PERERA J (2000) Probabilistic ecological risk assessment (ERA) incorporating geochemical speciation to determine bioavailable metals in freshwaters affected by acid rock drainage (ARD). In: Proc. $5^{\text {th }}$ International Conference on Acid Rock Drainage, 21-24 May 2000, Denver, CR, USA.

USEPA (United States Environmental Protection Agency) (1982) Development document for effluent limitations guidelines and standards for the coal mining point source category. EPA 440/182/057. USEPA, Washington DC.

VALKO M, MORRIS H and CRONIN MT (2005) Metals, toxicity and oxidative stress. Curr. Med. Chem. 12 1161-1208. https://doi. org/10.2174/0929867053764635

VAN DOREN SR, HALL MS, FRAZIER LB and LEACH FR (1984) A rapid cell culture assay of water quality. Bull. Environ. Contam. Toxicol. 32 220-226. https://doi.org/10.1007/BF01607489

VIARENGO A and NOTT JA (1993) Mechanisms of heavy metal cation homeostasis in marine invertebrates. Comp. Biochem. Phys. 104 355-372. https://doi.org/10.1016/0742-8413(93)90001-2

WINSTON GW and DI GIULIO RT (1991) Prooxidant and antioxidant mechanisms in aquatic organisms. Aquat. Toxicol. 19 137-161. https://doi.org/10.1016/0166-445X(91)90033-6

WOOD CM (2001) Toxic responses of the gill. In: Schlenk D and Benson WH (ed.) Target Organ Toxicity in Marine and Freshwater Teleosts. Taylor \& Francis, London. 